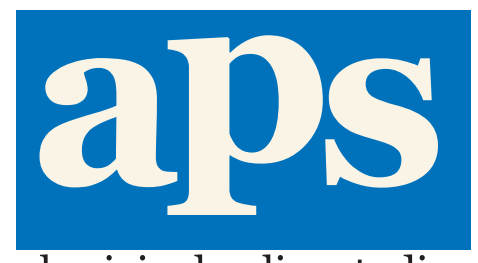

aboriginal policy studies

\title{
Article
}

\section{aboriginal policy studies - editor's introduction}

\author{
Chris Andersen
}

aboriginal policy studies, Vol. 1, no. 2, 2011, pp. 1-3

This article can be found at:

http://ejournals.library.ualberta.ca/index.php/aps/article/view/11684

ISSN: 1923-3299

Article DOI: $10.5663 / a p s . v 1 \mathrm{i} 2.11684$

aboriginal policy studies is an online, peer-reviewed and multidisciplinary journal that publishes original, scholarly, and policy-relevant research on issues relevant to Métis, non-status Indians and urban Aboriginal people in Canada. For more information, please contact us at apsjournal@ualberta.ca or visit our website at

www.ualberta.ca/NATIVESTUDIES/aps/

or

http://ejournals.library.ualberta.ca/index.php/aps/ 


\title{
aboriginal policy studies - editor's introduction
}

\author{
Chris Andersen \\ University of Alberta
}

Welcome to the second issue of aboriginal policy studies. While we will continue to carve out our niche over the coming issues by covering issues pertinent to Métis, non-status Indian and urban Aboriginals, it is quickly becoming clear to us that issues surrounding urban Aboriginals constitute a large bulk of the journal's analytic interest. This issue, for example, includes three articles that directly relate to issues pertinent to urban Aboriginal policy. Mary Jane Norris-one of Canada's leading demographic experts on Aboriginal language-explores in great depth the issue of Aboriginal languages in urban areas. This article is the first of a two-part series (the second will appear in the next issue of aboriginal policy studies). Likewise, Charles Horn, in his article, is exploring issues that relate to practical considerations around urban Aboriginal economic development as part of a larger scholarly grant allowing him to explore related issues. Jana Grekul and Petrina LaRocque document a different but growing issue in urban spaces - that of Aboriginal gangs - through their study on gang exit strategies for Aboriginal women. The issue also includes an article by Evelyn Peters, who has meticulously documented the strengths and limitations of the official enumeration of Indigenous peoples across the globe. Professor Peters' work, while examining an issue with broader implications, is also particularly important in the context of urban Aboriginal issues, as the statistics generated from such enumeration tend to reflect categories not meant for the distinctiveness of urban spaces (nor, I would argue, is their cross-tabulation with geographical residence sufficient to capture this distinctiveness).

In addition to the peer-reviewed articles, this issue's commentary section explores a number of issues important to the journal's focus. The

aboriginal policy studies, Vol. 1, no. 2, 2011

ISSN: 1923-3299

www.ualberta.ca/NATIVESTUDIES/aps/ 
first two commentaries set out debating positions on the meaning of Métis identity and were originally written for Malinda Smith's "Fedcan blog" series for the Canadian Federation of Social Sciences and Humanities (http://blog.fedcan.ca/). I wrote the first, titled "I'm Métis: what's your excuse?", as a critique of definitions of Métis identity linked to mixed ancestry. Instead, I attempted to set out the importance of thinking more nationally about Métis identity. The following week, Joyce Green (at the University of Regina) wrote a second piece positioning Métis identity in terms of its construction by the colonial nation-state over the past century. Finally, Chief Kim Baird of the Twassassin First Nation in Vancouver, BC generously agreed to write a piece on her First Nation's movement away from the Indian Act and towards an alternative conception of selfgovernment. Chief Baird's discussion, while dealing specifically with First Nations issues, nonetheless remains central to aboriginal policy studies' mandate: first, because of the Twassassin's geographical location near Vancouver; and, second, because of the issues that will pertain to "status" and "non-status" members of her First Nation.

In the book reviews and foundational documents section, we feature the text to the Indian Association of Alberta's "reply" to the government of Canada's "White Paper," titled Citizens Plus, and known more colloquially as "The Red Paper." Finally, Dr. Fiona Nicolls, a faculty member at the University of Queensland in Brisbane, Australia, has written a review of Yale Belanger's recently published First Nations Gaming in Canada. Given the location of most casinos invested in by First Nations, this book is of obvious and immediate importance to issues pertaining to urban Aboriginals.

I would like to end this introduction with a special plea and an information update. Regarding the information update: we have been able to add digital objective identifiers (DOIs) to many of the references from the first issue, as well as those in the second issue. DOIs are stable web links that allow you to directly access the bibliographic reference (assuming you have access to databases that carry it), which significantly reduces the time required to find and download such references. Regarding the plea, to researchers engaged in Métis and/or non-status Indian issues: while we have seen numerous submissions relating to urban Aboriginal issues, we have not yet been able to match those with similar numbers of submissions relating to Métis and non-status Indian policy issues. Partly this reflects the tremendous amount of research being undertaken on urban Aboriginal issues but, likewise, it also reflects the relatively small proportion of research 
on Métis and non-status Indian policy issues. If you yourself, or someone you know, is interested in submitting something on these issues, we would highly encourage you to do so.

Thank you, and please enjoy volume 1, issue two. As always, if you have any questions or concerns, please do not hesitate to contact us at apsjournal@ualberta.ca.

Chris Andersen

Editor, aboriginal policy studies 